\title{
Spatial Variations in Concentration, Compositions of Glomalin Related Soil Protein in Poplar Plantations in Northeastern China, and Possible Relations with Soil Physicochemical Properties
}

\author{
Qiong Wang, 1 Yan Wu, ${ }^{1,2}$ Wenjie Wang, ${ }^{1}$ Zhaoliang Zhong, \\ Zhongxue Pei, ${ }^{1}$ Jie Ren, ${ }^{1}$ Huimei Wang, ${ }^{1}$ and Yuangang $\mathrm{Zu}^{1}$ \\ ${ }^{1}$ Key Laboratory of Forest Plant Ecology, Northeast Forestry University, Harbin 150040, China \\ ${ }^{2}$ Daqing Normal University, Daqing 163712, China \\ Correspondence should be addressed to Wenjie Wang; wjwang225@163.com
}

Received 9 December 2013; Accepted 20 February 2014; Published 6 April 2014

Academic Editors: E. de Blas and G. Liu

Copyright (C) 2014 Qiong Wang et al. This is an open access article distributed under the Creative Commons Attribution License, which permits unrestricted use, distribution, and reproduction in any medium, provided the original work is properly cited.

\begin{abstract}
Concentration of Glomalin Related Soil Protein is reportedly close related to soil functions, but few data is available for GRSP compositional variations and function related to soil properties. In this paper, soils from $0-20 \mathrm{~cm}, 20-40 \mathrm{~cm}, 40-60 \mathrm{~cm}, 60-80 \mathrm{~cm}$, and $80-100 \mathrm{~cm}$ layers were collected in 72 poplar shelterbelts in Songnen Plain (6 regions) for implementing this data shortage. GRSP mainly consists of stretching of $\mathrm{O}-\mathrm{H}, \mathrm{N}-\mathrm{H}, \mathrm{C}-\mathrm{H}, \mathrm{C}=\mathrm{O}, \mathrm{COO}-, \mathrm{C}-\mathrm{O}$, and $\mathrm{Si}-\mathrm{O}-\mathrm{Si}$ and bending of $\mathrm{C}-\mathrm{H}$ and $\mathrm{O}-\mathrm{H}$. It has seven fluorescent substances of tyrosine-like protein, tryptophan-like protein, fulvic acid-like, humic acid-like, soluble microbial byproduct-like, nitrobenzoxadiazole-like, and calcofluor white-like, with characteristic X-ray diffraction peak at $2 \theta=$ $19.8^{\circ}$ and $129.3 \mathrm{~nm}$ grain size as well as $1.08 \%$ low crystallinity. Large spatial variations (intersite and intrasite down profile) were found in either GRSP concentration or these compositional traits. Regression analysis clearly manifested that soil $\mathrm{pH}$ should be responsible for these variations. However, negative relations between soil bulk density and GRSP quantity were observed, but not its compositional traits. These basic data in poplar shelterbelt forests are good for understanding the underlying mechanism of GRSP in soil functional maintenance.
\end{abstract}

\section{Introduction}

Glomalin Related Soil Protein (GRSP) is one kind of glycoprotein which contains metal ions $\left(\mathrm{Fe}^{3+}\right)$ from arbuscular mycorrhizal fungi (AMF) $[1,2]$. After its first discovery in 1996, immune fluorescent reactions, chemical stability, extracting methods $[1,2]$, and wide distribution in variable soil ecosystems and land uses [3-5] are reported. Both abiotic and biological factors such as elevated $\mathrm{CO}_{2}$ [6], global warming [7], climate conditions, vegetation types [3, 8], and a variety of agricultural measures could affect GRSP concentration in soils. Technological advances in infrared spectroscopy [9], ultraviolet absorbance spectrum [10], 3D fluorescence spectroscopy [11], X-ray diffraction [12] made it possible to characterize compositional differences in a more detailed way and these techniques favor the recent advances in GRSP composition functionality [9] and complexity [12]. Although relations between GRSP concentration and soil aggregates stability, concentration of soil organic $\mathrm{C}, \mathrm{N}$ are well known $[13,14]$, relations between these compositional differences and soil properties are not defined yet, and quantifying GRSP compositional differences can facilitate the definition of their functions in regulating soil physical chemical properties $[9,12]$.

Worldwide distribution of poplar plantations shows their importance in afforestation practices, and over 710 million $\mathrm{hm}^{2}$ of them distribute in China (1/5 of world total), ranking top one in the world [15]. In most cases, poplar shelterbelt forests playing important roles in breaking wind, fixing sands, reducing sound pollution, and capturing carbon in China. As farmland shelterbelts, poplar plantations' function is to 
TABLE 1: Basic information of 6 sampling sites.

\begin{tabular}{lccccc}
\hline Location & Soil type & China soil taxonomy & Longitude & Latitude & Average altitude \\
\hline Mingshui & Phaeozem & Pachic argi-udic Isohumosols & $125^{\circ} 41^{\prime} \sim 126^{\circ} 42^{\prime}$ & $45^{\circ} 08^{\prime} \sim 45^{\circ} 43^{\prime}$ & $271.4 \mathrm{~m}$ \\
Lanling & Chernozem & Typic-calci-ustic argosols & $125^{\circ} 13^{\prime} \sim 126^{\circ} 18^{\prime}$ & $45^{\circ} 13^{\prime} \sim 45^{\circ} 18^{\prime}$ & $400.0 \mathrm{~m}$ \\
Fuyu & Chernozem & Typic-calci-ustic argosols & $124^{\circ} 48^{\prime} \sim 126^{\circ} 51^{\prime}$ & $45^{\circ} 37^{\prime} \sim 45^{\circ} 40^{\prime}$ & $162.4 \mathrm{~m}$ \\
Zhaozhou & Solonetz & Typic takyri-alkalic halosols & $124^{\circ} 55^{\prime} \sim 125^{\circ} 12^{\prime}$ & $45^{\circ} 41^{\prime} \sim 45^{\circ} 49^{\prime}$ & $150.0 \mathrm{~m}$ \\
Zhaodong & Solonetz & Typic takyri-alkalic halosols & $125^{\circ} 22^{\prime} \sim 126^{\circ} 22^{\prime}$ & $45^{\circ} 10^{\prime} \sim 46^{\circ} 20^{\prime}$ & $160.5 \mathrm{~m}$ \\
Dumeng & Cambosols & Typic dark aquic cambosols & $124^{\circ} 19^{\prime} \sim 125^{\circ} 12^{\prime}$ & $45^{\circ} 46^{\prime} \sim 46^{\circ} 55^{\prime}$ & $146.0 \mathrm{~m}$ \\
\hline
\end{tabular}

defend natural disasters and protect food products in Northeastern China. Symbiotic relationships between over $90 \%$ plants and AMF can improve the viability of adversity plants [16]. After AMF infected plants, external hyphae form a huge network in soils [17], transfer information between same or different plants [18], and secret GRSP with function of soil structure modification [19]. There were many studies on farmland shelterbelts ecological protecting function in $\mathrm{NE}$ China (e.g., [15]) and intersites and intrasites spatial variations both in GRSP concentration and compositional traits should be a basis for understanding function of GRSP in maintaining optimal soil properties.

GRSP is the typical compounds secreted by AM hyphae [18]; we postulate that large spatial (intrasite down vertical profile and intersite) variations in GRSP (easily extractable GRSP, EE-GRSP; total GRSP, T-GRSP) should exist in both compositional traits and quantity, and some abiotic factors, such as soil $\mathrm{pH}$ and so forth, should be responsible for such spatial variations. For approaching this hypothesis, Songnen Plain with a flat topography, relative consistent climate, and abundant of poplar farmland shelterbelts [15] was selected for conducting this study, and 360 soil samples from 72 poplar shelterbelts were sampled for this paper. The aim was to explore the quantity and compositional variations of GRSP between and within sites and down profile, and regression analysis was thereafter adopted for finding their possible contribution to soil physicochemical changes. The following scientific questions will be answered, that is, what are the compositional features of GRSP from the viewpoints of infrared spectrum, fluorescent spectrum, and X-ray diffraction? How large variations in vertical soil profile and different sites were found in these compositional parameters and concentration of GRSP? Which soil parameters were possibly related to such quantity and compositional variations in GRSP?

\section{Material and Methods}

2.1. Natural Condition of Study Sites and Preparation of Soil Samples. Songnen Plain is located in the middle of Northeast China and crosses Heilongjiang Province, Jilin Province, and Inner Mongolia Autonomous Region, and the total area is $182,800 \mathrm{~km}^{2}$, involving a population of 36 million. Songnen Plain is one of the most important bases for large-scale commodity grain and animal husbandry for China. Poplar shelterbelts forests were planted widely since the launch of national "three-north" shelterbelts project in 1978 [15]. In this paper, poplar shelterbelts were general 3-8 rows trees with mature-aged poplars, and some younger shelterbelts were tens of rows trees. The average of tree density, tree height, and diameter at breast height was, respectively, 3600 trees ha ${ }^{-1}$, $14.91 \mathrm{~m}$, and $23.18 \mathrm{~cm}$.

Soil samples were collected from 72 shelterbelt plantations in 6 typical regions distributed in Songnen Plain (Table 1). Soil classification was based on [20]. In each of the 6 regions, 12 soil profiles were digging out in 12 different shelterbelt forests. In each soil profile, 5 soil samples were collected with a $100 \mathrm{~cm}^{3}$ cutting ring from soil layers of $0-20 \mathrm{~cm}$, $20-40 \mathrm{~cm}, 40-60 \mathrm{~cm}, 60-80 \mathrm{~cm}$, and $80-100 \mathrm{~cm}$. In total, 360 soil samples $(6 \times 12 \times 5=360)$ were collected. All samples were collected from June to August 2012. After fully airdrying and excluding small stones, distinguishable plant roots, and other debris, samples passed through $0.25 \mathrm{~mm}$ sieve were used for laboratory analysis. The reason for this sieve size selection is that larger proportions of GRSP were distributed in $0.21 \mathrm{~mm}-0.50 \mathrm{~mm}$ macroaggregates [21]; moreover, soil samples from $0.25 \mathrm{~mm}$ to $1 \mathrm{~mm}$ sieves had similar GRSP concentration in China [22].

2.2. Determination of Soil Physicochemical Properties. Soil $\mathrm{pH}$ was measured in solution with $1 \mathrm{~g}$ soil sample in $5 \mathrm{~mL}$ deionized water and it was determined with a precise $\mathrm{pH}$ meter of Sartorius PB10 (Sartorius, Germany). Soil electrical conductivity (EC) was determined with an EC meter (DDS307, Shanghai Precision Scientific Instruments Co., Ltd., China). Soil moisture was calculated as (fresh weight - dry weight)/dry weight $\times 100 \%$. Soil bulk density was calculated as the ratio between air-dried soil mass and the soil volume $\left(400 \mathrm{~cm}^{3}\right)$.

2.3. Extraction and Determination of GRSP. Extraction and determination of GRSP in soil samples was according to the method described by Wright with a slight improvement [5]. For EE-GRSP, samples of $0.5000 \mathrm{~g}$ soil were subjected to extraction with $4 \mathrm{~mL}$ of $20 \mathrm{mM}$ citrate, $\mathrm{pH}=7.0$, and autoclaving for $30 \mathrm{~min}$ at $121^{\circ} \mathrm{C}$. The T-GRSP was extracted from $0.1000 \mathrm{~g}$ of soil with $4 \mathrm{~mL}$ of $50 \mathrm{mM}$ citrate, $\mathrm{pH}=8.0$, and autoclaving for $1 \mathrm{~h}$ at $121^{\circ} \mathrm{C}$. In both cases, the supernatant was separated by centrifugation at $4000 \mathrm{rpm}$ for $6 \mathrm{~min}$ and supernatant was collected. For T-GRSP, the procedure described was repeated several times (autoclaving for $30 \mathrm{~min}$ at $121^{\circ} \mathrm{C}$ ) on the same sample until the reddish brown color typical of GRSP disappeared from the supernatant, combining all extracts from a soil sample. The protein content in the crude 
extract was determined by Bradford assay with bovine serum albumin as the standard. GRSP storage (EE and T) was calculated as the product of GRSP concentration (EE and T), soil depth $(20 \mathrm{~cm})$, and soil bulk density.

\subsection{Determination of Composition Traits of Purified T-GRSP.} Soil samples from surface $20 \mathrm{~cm}$ soil in each of the 6 regions were mixed as a composite sample for purifications of $\mathrm{T}$ GRSP. Purification of T-GRSP was according to [12]: $1.00 \mathrm{~g}$ soil sample was put in $50 \mathrm{~mL}$ centrifuge tubes, $8 \mathrm{~mL}$ of $50 \mathrm{mM}$ citrate extraction solvent at $\mathrm{pH}=8.0$. The sample was oscillated for half a minute on the oscillator to ensure mixing thoroughly and extracted at $121^{\circ} \mathrm{C}$ for $60 \mathrm{~min}$. Then the sample was centrifuged at $4000 \mathrm{rpm}$ for $15 \mathrm{~min}$, and the supernatant was removed to centrifuge cups. The extraction process was repeated, continuous extraction was carried out until the supernatant no longer showed the typical red brown. All the collected extraction was then precipitated by titrating hydrochloric acid and then centrifuged at $4000 \mathrm{rpm}$ for $15 \mathrm{~min}$. The pellets under the centrifuge tube were resolubilized in $0.1 \mathrm{M}$ sodium hydroxide and dialyzed against deionized water for $60 \mathrm{~h}$ (dialysis bag, DW =8000-14000 Da, Scientific Research Special, USA). After dialysis, The purified dialyzate was centrifuged at $10000 \mathrm{rpm}$ for $10 \mathrm{~min}$ to remove any extraneous particles. The supernatant was then immediately freeze-dried with vacuum freeze drier (Scientz-10N, Ningbo Scientz Biotechnology Co., Ltd., China).

Infrared Spectroscopy Measurement. The samples were diluted with $1 \% \mathrm{KBr}$ mixing powder and separately pressed to obtain self-supporting disks. Functional traits were determined with IRAffinity-1 infrared spectrometer model (SHIMADZU, Japan) with a spectral range of $4000-500 \mathrm{~cm}^{-1}$. For each peak in the spectrum, the absorption peak area could semiquantitatively reflect the concentration of the functional trait matching with this peak. The match between functional traits and peak wave numbers was from [23] and is described as in Figure 1.

X-Ray Diffraction (XRD) Measurement. XRD patterns were collected in transmission by using an X-ray diffraction meter (D/Max 2200, Rigaku, Japan) with a rotating anode (Philips) and $\mathrm{Cu} \mathrm{K} \alpha 1$ radiation generated at $30 \mathrm{~mA}$ and $40 \mathrm{kV}$. The range of $2 \theta$ diffraction angles examined was $10^{\circ}-40^{\circ}$ with steps of $0.02^{\circ}$ and a measuring time of $0.3 \mathrm{~s}$ per step. In the analysis of XRD data, the original data were rectified using the Jade program to eliminate $\mathrm{K} \alpha$ and then obtain the XRD pattern for a sample. The upper area $(a c)$, which was separated with the smooth curve connecting each point of minimum intensity, corresponded to the crystalline portion, and the lower area was the background containing the amorphous portion $(a b)$. The Jade 5 program was used to calculate grain size and relative crystallinity (relative crystallinity $=c /(a c+$ $a b)$ ) [24].

UV Spectrophotometer Measurement. $1.000 \mathrm{mg}$ freeze-dried T-GRSP samples were put in $10 \mathrm{~mL}$ centrifuge tubes, with $1 \mathrm{~mL}$ of $0.1 \mathrm{M}$ sodium hydroxide solution dissolved, and

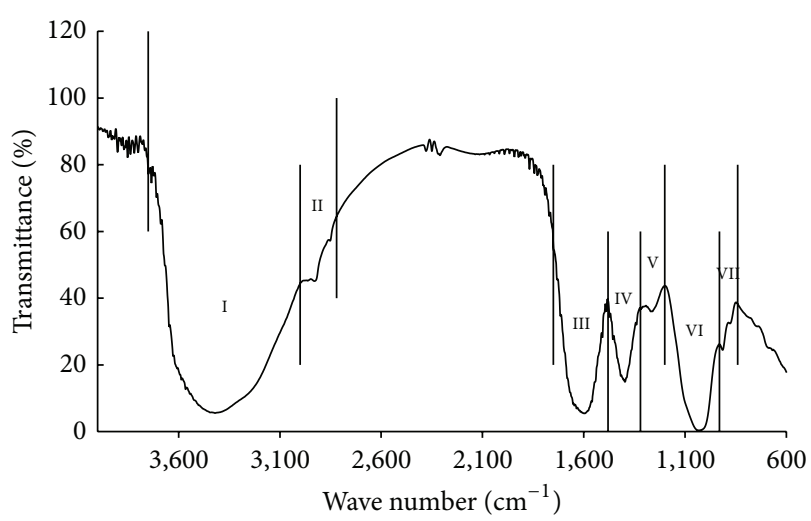

FIGURE 1: Schematic diagram with partition method of functional traits of GRSP by using infrared spectrum. Note: functional trait I (wave number of $3750-3000 \mathrm{~cm}^{-1}$ ) is a mixture of $\mathrm{O}-\mathrm{H}$ stretching of carboxylic acid, phenols, alcohols, clay minerals and oxides, $\mathrm{N}-\mathrm{H}$ stretching of organic amines, amides, and aromatic $\mathrm{C}-\mathrm{H}$ stretching. Functional trait II (wave number of $3000-2820 \mathrm{~cm}^{-1}$ ) is aliphatic C$\mathrm{H}$ stretching. Functional trait III (wave number of $1750-1480 \mathrm{~cm}^{-1}$ ) is a mixture of $\mathrm{C}=\mathrm{O}$ stretching of carboxylic acid, ketones and amides, and asymmetric COO- stretching of carboxylic acid salts. Functional trait IV (wave number of $1480-1320 \mathrm{~cm}^{-1}$ ) is a mixture of symmetric COO- stretching of carboxylic acid salts and $\mathrm{C}-\mathrm{H}$ bending of $-\mathrm{CH}_{2}-$ and $-\mathrm{CH}_{3}$ groups. Functional trait $\mathrm{V}$ (wave number of $1320-1200 \mathrm{~cm}^{-1}$ ) is a mixture of C-O stretching and O$\mathrm{H}$ bending of $-\mathrm{COOH}$. Functional trait VI (wave number of 1200 $930 \mathrm{~cm}^{-1}$ ) is a mixture of $\mathrm{C}-\mathrm{O}$ stretching of polysaccharide and $\mathrm{Si}-$ $\mathrm{O}-\mathrm{Si}$ stretching in clay minerals and oxides. Functional trait VII (wave number of $930-840 \mathrm{~cm}^{-1}$ ) is $\mathrm{O}-\mathrm{H}$ bending of structural $\mathrm{OH}$ in clay minerals and oxides.

diluted 10-fold. It was determined with the UV-visible spectrophotometer of UV-2550 (SHIMADZU Co., Kyoto, Japan), scanning wavelength range: $250-450 \mathrm{~nm}$. OD value and the range of maximum absorption wavelength of T-GRSP were obtained in the figure of the program.

Fluorescence Spectrometer Measurement. $1.000 \mathrm{mg}$ freezedried T-GRSP samples were put in $10 \mathrm{~mL}$ centrifuge tubes, with $1 \mathrm{~mL}$ of $0.1 \mathrm{M}$ sodium hydroxide solution dissolved, and diluted 5-fold, using a Hitachi F-7000 fluorescence spectrometer (Hitachi High Technologies, Tokyo, Japan) with a 700 -voltage xenon lamp at room temperature $\left(20 \pm 2^{\circ} \mathrm{C}\right)$. Readings were collected in ratio mode (S/R) (the default mode of F-7000 fluorescence spectrometer), using a scanning speed of $2400 \mathrm{~nm} \cdot \mathrm{min}^{-1}$. The scanning ranges were $220-$ $470 \mathrm{~nm}$ for excitation and $280-650 \mathrm{~nm}$ for emission. The bandpass widths were $5 \mathrm{~nm}$ for both excitation and emission. The range of different excitation/emission wavelength of the fluorescence spectra classified the dissolved organic matter in T-GRSP into seven fluorescent materials in accordance with [25] and identification support from Microspheres Online (http://www.microspheres.us/microsphere-basics/fluorochromes-excitation-emission-wavelengths/248.html) (Figure 2).

2.5. Data Analysis. Two-way analysis of variance (ANOVA) was used to identify the site- and soil depth-related variations 


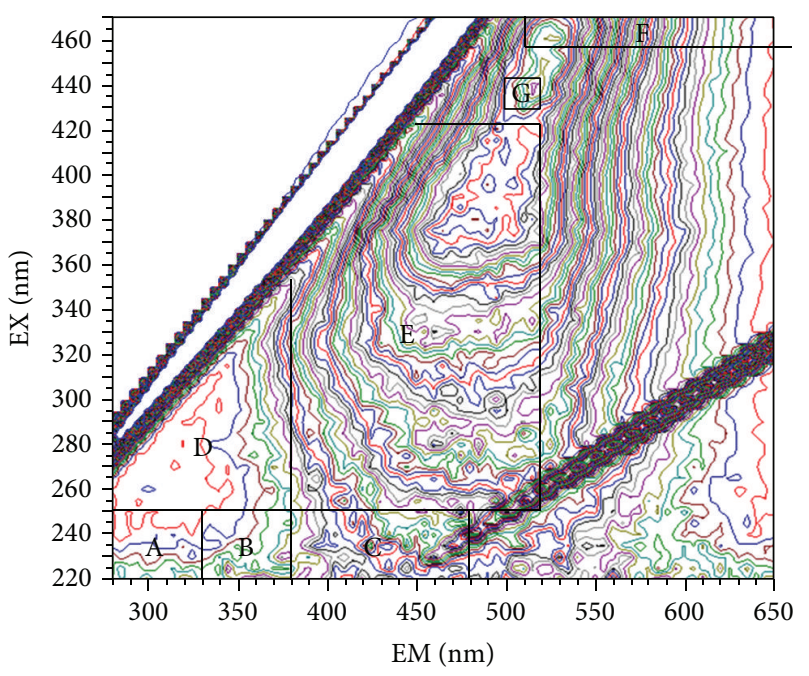

(a)

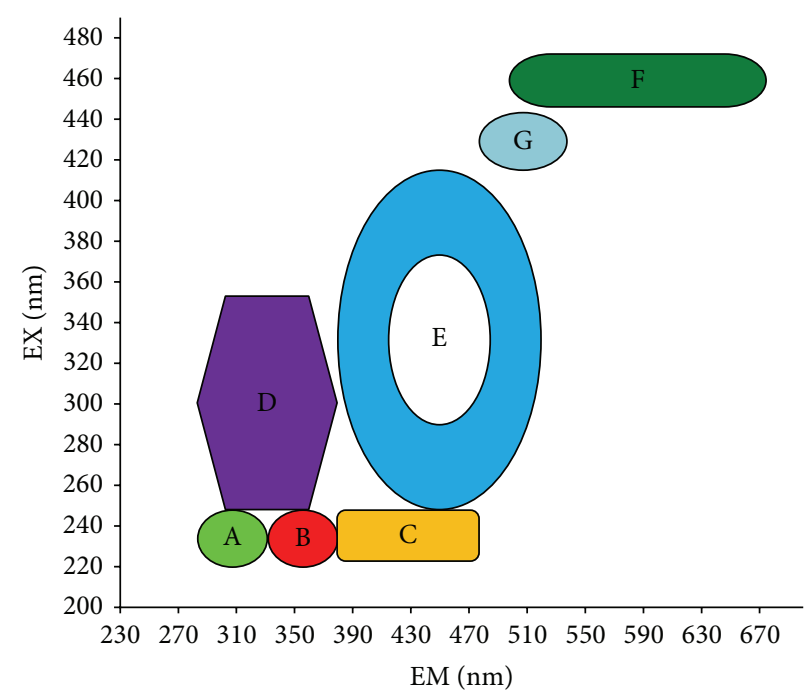

(b)

FIGURE 2: Schematic diagrams with partition method of fluorescent substances of GRSP by using 3D fluorescence spectrum. (a) Fingerprint of the partition of fluorescent substances; (b) pattern of the partition of fluorescent substances. Note: A: tyrosine-like protein, $220-250 \mathrm{~nm}$ in excitation and 280-330 nm in emission; B: tryptophan-like protein, 220-250 nm in excitation and 330-380 nm in emission; C: fulvic acid-like, $220-250 \mathrm{~nm}$ in excitation and 380-480 nm in emission; D: soluble microbial byproduct-like, 250-360 $\mathrm{nm}$ in excitation and 280-380 $\mathrm{nm}$ in emission; E: humic acid-like, $250-420 \mathrm{~nm}$ in excitation and 380-520 nm in emission; F: nitrobenzoxadiazole-like, $460-470 \mathrm{~nm}$ in excitation and 510-650 $\mathrm{nm}$ in emission; G: calcofluor white-like, $440 \mathrm{~nm}$ in excitation and 500-520 $\mathrm{nm}$ in emission.

on concentration of T-GRSP and EE-GRSP, soil physicochemical properties, and their possible interactions, with LSD pairwise comparison for multiple comparison. Regression analysis was used to find linear relations between GRSP quantity, compositional traits, and variable soil physicochemical properties. All analysis was performed by SPSS 17.0 (SPSS, USA).

\section{Results}

3.1. Variations in Soil Physicochemical Properties: Sites, Soil Layers, and Interaction. Different soil $\mathrm{pH}$, soil bulk density, and soil moisture differed among sites $(P<0.01)$ and among soil layers $(P<0.01)$, while different EC was found only in different soil layers $(P<0.01)$. These site variations were similar at different soil layers because no interaction between sites and soil layers was found $(P>0.05)$ (Table 2).

Estimated marginal means showed the magnitude of siteand soil layer-related variations (Table 2). For different sites, soil $\mathrm{pH}$ in Zhaozhou was 1.15-fold higher than the lowest value in Mingshui; soil bulk density in Dumeng was the highest; soil moisture showed a pattern of Fuyu > Mingshui > Zhaodong $>$ Zhaozhou $=$ Lanling $>$ Dumeng; EC in Fuyu was 1.88 -fold higher than the lowest site. As deepening of soil, increasing soil $\mathrm{pH}$ and soil bulk density but decreasing soil moisture and EC were observed (Table 2).

\subsection{Variations of GRSP (T-GRSP, EE-GRSP) Concentration} in Different Sites and Soil Layers. GRSP (T-GRSP, EE-GRSP) concentration significantly differed at different sites and soil layers. Moreover, as shown for the larger $F$ value, site-related variations for all 4 parameters were much larger than those from soil layers (Table 3). The significant interaction between site and soil layer on GRSP showed site variations were different at different soil layers $(P<0.01)$ (Table 3$)$.

The size of site- and soil layer-related variations were observed in estimated marginal means (Table 3). For site variations, T-GRSP showed a similar pattern of Mingshui > Zhaodong $>$ Lanling $>$ Dumeng $>$ Fuyu $>$ Zhaozhou; some variations (e.g., Mingshui and Zhaodong) were statistically significant $(P<0.05)$. For vertical variations, with the deepening of soil layers, decreasing T-GRSP was observed.

For site variations of EE-GRSP both in concentration and storage, the similar pattern of Mingshui $>$ Dumeng $>$ Fuyu $>$ Zhaozhou $>$ Lanling $>$ Zhaodong was found. Some variations (e.g., Mingshui and Dumeng) were statistically significant $(P<0.05)$, while some others (e.g., Dumeng and Fuyu) were not significant $(P>0.05)$. For vertical variations, decreasing EE-GRSP concentration and storage were observed with the deepening of soil layers. EE-GRSP concentration showed that $0-20 \mathrm{~cm}$ soil layer was 2.58 -fold higher than the lowest value in $80-100 \mathrm{~cm}$ soil layer $\left(0.26 \mathrm{mg} \cdot \mathrm{g}^{-1}\right)(P<0.05)$.

On average of pooled data, T-GRSP concentration, EEGRSP concentration, T-GRSP storage, and EE-GRSP storage were, respectively, $3.93 \mathrm{mg} \cdot \mathrm{g}^{-1}, 0.43 \mathrm{mg} \cdot \mathrm{g}^{-1}, 107.89 \mathrm{mg} \cdot \mathrm{cm}^{-2}$, and $11.89 \mathrm{mg} \cdot \mathrm{cm}^{-2}$ (Table 3 ).

3.3. Site Variations in Composition-Related Functional Traits of Purified T-GRSP. Result of infrared spectroscopy was summarized as follows: for different functional traits, the size of the site variations was different. For example, in the case of functional trait VII (O-H bending), peak value in Zhaozhou was 2.10-fold higher than the lowest value in Fuyu 
TABLE 2: Two-way ANOVA results on spatial (site, soil layer) variations of different soil physicochemical properties in poplar shelterbelt forests in Songnen Plain.

\begin{tabular}{|c|c|c|c|c|}
\hline Index & $\mathrm{pH}$ value & $\mathrm{EC}$ & Bulk density & Soil moisture \\
\hline \multicolumn{5}{|l|}{ Site } \\
\hline$F$ & 55.21 & 2.08 & 29.76 & 111.05 \\
\hline$P$ value & 0.000 & 0.068 & 0.000 & 0.000 \\
\hline \multicolumn{5}{|l|}{ Soil layer } \\
\hline$F$ & 7.13 & 3.90 & 7.62 & 9.34 \\
\hline$P$ value & 0.000 & 0.004 & 0.000 & 0.000 \\
\hline \multicolumn{5}{|l|}{ Interaction } \\
\hline$F$ & 0.26 & 0.56 & 1.55 & 1.22 \\
\hline$P$ value & 1.000 & 0.937 & 0.062 & 0.232 \\
\hline \multicolumn{5}{|c|}{ Site-related differences (mean and their statistical significance) } \\
\hline Dumeng & $8.49^{\mathrm{a}}$ & $105.7^{\mathrm{ab}}$ & $1.51^{\mathrm{a}}$ & $5^{\mathrm{d}}$ \\
\hline Fuyu & $8.46^{\mathrm{a}}$ & $152.1^{\mathrm{a}}$ & $1.40^{\mathrm{bc}}$ & $17^{\mathrm{a}}$ \\
\hline Lanling & $7.68^{\mathrm{b}}$ & $122.6^{\mathrm{ab}}$ & $1.43^{\mathrm{b}}$ & $9^{c}$ \\
\hline Mingshui & $7.44^{\mathrm{b}}$ & $80.9^{\mathrm{b}}$ & $1.32^{\mathrm{d}}$ & $16^{\mathrm{a}}$ \\
\hline Zhaodong & $8.51^{\mathrm{a}}$ & $114.9^{\mathrm{ab}}$ & $1.39^{\mathrm{bc}}$ & $13^{\mathrm{b}}$ \\
\hline Zhaozhou & $8.53^{\mathrm{a}}$ & $139.5^{\mathrm{ab}}$ & $1.38^{\mathrm{c}}$ & $9^{c}$ \\
\hline Largest/lowest ratio & 1.15 & 1.88 & 1.14 & 1.89 \\
\hline \multicolumn{5}{|c|}{ Soil layer-related differences (mean and their statistical significance) } \\
\hline $0-20 \mathrm{~cm}$ & $8.08^{\mathrm{ab}}$ & $105.2^{\mathrm{b}}$ & $1.37^{\mathrm{c}}$ & $13^{\mathrm{a}}$ \\
\hline $20-40 \mathrm{~cm}$ & $8.00^{\mathrm{b}}$ & $173.7^{\mathrm{a}}$ & $1.39^{\mathrm{bc}}$ & $12^{\mathrm{ab}}$ \\
\hline $40-60 \mathrm{~cm}$ & $8.15^{\mathrm{ab}}$ & $114.4^{\mathrm{ab}}$ & $1.41^{\mathrm{abc}}$ & $11^{\mathrm{ab}}$ \\
\hline $60-80 \mathrm{~cm}$ & $8.32^{\mathrm{a}}$ & $110.2^{\mathrm{b}}$ & $1.43^{\mathrm{ab}}$ & $10^{\mathrm{b}}$ \\
\hline $80-100 \mathrm{~cm}$ & $8.38^{\mathrm{a}}$ & $92.9^{\mathrm{b}}$ & $1.43^{\mathrm{a}}$ & $10^{\mathrm{b}}$ \\
\hline Largest/lowest ratio & 1.05 & 1.87 & 1.04 & 1.30 \\
\hline Mean of pooled data & 8.19 & 119.28 & 1.41 & 11 \\
\hline
\end{tabular}

Note: Different lowercases indicate the related differences between different soil layers or between different sites were statistically significant $(P<0.05)$.

(17.3), while in the case of functional trait III (a mixture of $\mathrm{C}=\mathrm{O}$ stretching of carboxylic acid, ketones, and amides and asymmetric COO- stretching of carboxylic acid salts), peak value in Zhaodong was only 1.12-fold higher than the lowest in Dumeng (1949.7). Average of functional traits showed that I (8050.9) > III (2039.9) > VI (1277.3) > IV (500.9) > II (258.8) $>$ V (95.1) > VII (25.7) (Table 4).

Result of X-ray diffraction was summarized as follows: diffraction peak position of GRSP was in $2 \theta=19.8^{\circ}$; the relative crystallization and grain size of T-GRSP were derived from XDR data (Table 5). Dumeng showed the highest grain size $(174 \mathrm{~nm})$, followed by Fuyu $(138 \mathrm{~nm})$, whereas the lowest value was found in Zhaodong $(98 \mathrm{~nm})$. Relative crystallinity showed Mingshui $(1.98 \%)>$ Lanling $(1.35 \%)>$ Fuyu $(1.05 \%)>$ Dumeng $(0.73 \%)>$ Zhaodong $(0.7 \%)>$ Zhaozhou $(0.69 \%)$, and site variations were 2.71 -fold. The mean relative crystallinity and grain size were, respectively, $1.08 \%$ and $129.3 \mathrm{~nm}$.

Result of OD values and fluorescent intensity at $295 \mathrm{~nm}$ was summarized as follows: the wavelength of maximum absorption (OD) was at $294.4 \pm 1.8 \mathrm{~nm}$ (Table 5), and 1.34fold variations were observed between Mingshui, the highest site, and Zhaodong, the lowest site (1.02). At $295 \mathrm{~nm}$, the peak excitation fluorescence had 1.49-fold variations between Fuyu and Zhaodong (20.53) (Table 5).
Result of 3D fluorescent spectroscopy was summarized as follows: Table 5 showed that GRSP is a mixture of at least seven fluorescent compounds (tyrosine-like protein, tryptophan-like protein, fulvic acid-like, soluble microbial byproduct-like, humic acid-like, nitrobenzoxadiazole-like, calcofluor white-like), but 1.18-4.50-fold site variations were found. For example, the highest value of tyrosine-like protein was in Zhaozhou (7.78), about 4.50-fold higher than the lowest value in Zhaodong. Humic acid-like had 1.64-fold variations. The highest value of calcofluor white-like was in Dumeng (59.17), and the lowest value was in Zhaodong (50.07) (not detectable in Mingshui and Zhaozhou). Average fluorescent intensity showed a pattern of nitrobenzoxadiazole-like $>$ calcofluor white-like $>$ humic acid-like $>$ fulvic acid-like $>$ tryptophan-like protein $>$ tyrosine-like protein $>$ soluble microbial byproduct-like.

3.4. Regression Analysis between GRSP Concentration, Compositional Traits, and Soil Physicochemical Properties. Soil pH, soil bulk density, and soil moisture were significantly linearly correlated with T-GRSP and EE-GRSP concentration, respectively $(P<0.01)$. Both T-GRSP and EE-GRSP storage showed a similar pattern $(P<0.01)$ and data were not shown here. $R^{2}$ for linear correlations between $\mathrm{pH}$ and quantity of GRSP 
TABLE 3: Two-way ANOVA results on spatial (site, soil layer) varaitions of GRSP (T-GRSP, EE-GRSP) concentration in poplar shelterbelt forests in Songnen Plain.

\begin{tabular}{|c|c|c|c|c|}
\hline Index & T-GRSP concentration & T-GRSP storage & EE-GRSP concentration & EE-GRSP storage \\
\hline \multicolumn{5}{|l|}{ Site } \\
\hline$F$ & 62.75 & 54.94 & 65.59 & 57.53 \\
\hline$P$ value & 0.000 & 0.000 & 0.000 & 0.000 \\
\hline \multicolumn{5}{|l|}{ Soil layer } \\
\hline$F$ & 64.87 & 59.21 & 39.32 & 35.32 \\
\hline$P$ value & 0.000 & 0.000 & 0.000 & 0.000 \\
\hline \multicolumn{5}{|l|}{ Interaction } \\
\hline$F$ & 2.14 & 2.07 & 1.14 & 1.28 \\
\hline$P$ value & 0.003 & 0.005 & 0.310 & 0.187 \\
\hline \multicolumn{5}{|c|}{ Site-related differences (mean and their statistical significance) } \\
\hline Dumeng & $2.93^{\mathrm{cd}}$ & $87.46^{\mathrm{cd}}$ & $0.48^{\mathrm{b}}$ & $14.32^{\mathrm{b}}$ \\
\hline Fuyu & $2.65^{\mathrm{d}}$ & $71.66^{\mathrm{d}}$ & $0.38^{\mathrm{bc}}$ & $10.40^{\mathrm{bc}}$ \\
\hline Lanling & $4.05^{\mathrm{c}}$ & $115.00^{c}$ & $0.30^{\mathrm{cd}}$ & $8.78^{\mathrm{cd}}$ \\
\hline Mingshui & $6.60^{\mathrm{a}}$ & $172.57^{\mathrm{a}}$ & $0.87^{\mathrm{a}}$ & $22.88^{\mathrm{a}}$ \\
\hline Zhaodong & $5.25^{\mathrm{b}}$ & $143.91^{\mathrm{b}}$ & $0.22^{\mathrm{d}}$ & $6.01^{\mathrm{d}}$ \\
\hline Zhaozhou & $2.10^{\mathrm{d}}$ & $56.76^{\mathrm{d}}$ & $0.33^{\mathrm{cd}}$ & $8.94^{\mathrm{cd}}$ \\
\hline Largest/lowest ratio & 3.14 & 3.04 & 3.95 & 3.81 \\
\hline \multicolumn{5}{|c|}{ Soil layer-related differences (mean and their statistical significance) } \\
\hline $0-20 \mathrm{~cm}$ & $6.29^{\mathrm{a}}$ & $169.83^{\mathrm{a}}$ & $0.67^{\mathrm{a}}$ & $18.26^{\mathrm{a}}$ \\
\hline $20-40 \mathrm{~cm}$ & $4.51^{\mathrm{b}}$ & $123.07^{\mathrm{b}}$ & $0.51^{\mathrm{b}}$ & $14.06^{\mathrm{b}}$ \\
\hline $40-60 \mathrm{~cm}$ & $3.81^{\mathrm{bc}}$ & $105.25^{\mathrm{bc}}$ & $0.38^{\mathrm{bc}}$ & $10.50^{\mathrm{bc}}$ \\
\hline $60-80 \mathrm{~cm}$ & $2.92^{\mathrm{cd}}$ & $81.82^{\text {cd }}$ & $0.33^{\mathrm{c}}$ & $9.20^{\mathrm{c}}$ \\
\hline $80-100 \mathrm{~cm}$ & $2.11^{\mathrm{d}}$ & $59.50^{\mathrm{d}}$ & $0.26^{\mathrm{c}}$ & $7.42^{\mathrm{c}}$ \\
\hline Largest/lowest ratio & 2.98 & 2.85 & 2.58 & 2.46 \\
\hline Mean of pooled data & 3.93 & 107.89 & 0.43 & 11.89 \\
\hline
\end{tabular}

Note: Different lowercases indicate the related differences between different soil layers or between different sites were statistically significant $(P<0.05)$.

TABLE 4: Differences of absorption peak area of functional traits of T-GRSP at different sites in Songnen Plain.

\begin{tabular}{|c|c|c|c|c|c|c|c|}
\hline \multirow{2}{*}{ Site } & \multicolumn{7}{|c|}{ The absorption peak area of functional traits of different wave numbers } \\
\hline & $3750-3000 \mathrm{~cm}^{-1}$ & $3000-2820 \mathrm{~cm}^{-1}$ & $1750-1480 \mathrm{~cm}^{-1}$ & $1480-1320 \mathrm{~cm}^{-1}$ & $1320-1200 \mathrm{~cm}^{-1}$ & $1200-930 \mathrm{~cm}^{-1}$ & $930-840 \mathrm{~cm}^{-1}$ \\
\hline Dumeng & $7293.0(634.2)$ & $331.3(115.8)$ & $1949.7(185.1)$ & $520.7(92.9)$ & $102.3(34.5)$ & $1150.0(154.1)$ & $26.7(9.6)$ \\
\hline Fuyu & $8052.3(727.2)$ & $291.3(99.0)$ & $2019.3(56.9)$ & $444.0(29.8)$ & $113.0(42.5)$ & $1187.7(47.9)$ & $17.3(1.2)$ \\
\hline Lanling & $8559.0(1235.2)$ & $176.3(24.1)$ & $2045.7(354.9)$ & $483.3(67.7)$ & $59.0(12.5)$ & $1437.0(240.9)$ & $24.0(7.5)$ \\
\hline Mingshui & $8489.3(379.2)$ & $185.3(10.1)$ & $2083.0(137.5)$ & $536.7(89.8)$ & $65.7(21.1)$ & $1508.3(103.8)$ & $31.3(11.2)$ \\
\hline Zhaodong & 8203.7 (939.4) & $301.3(85.5)$ & $2181.7(165.3)$ & $567.3(58.5)$ & $114.0(25.5)$ & $1205.3(135.7)$ & $18.3(1.5)$ \\
\hline Zhaozhou & $7708.0(623.5)$ & $267.3(46.3)$ & $1960.0(162.8)$ & $453.3(62.9)$ & $116.7(26.1)$ & 1175.7 (134.4) & $36.3(11.0)$ \\
\hline Largest/lowest ratio & 1.17 & 1.88 & 1.12 & 1.28 & 1.98 & 1.31 & 2.10 \\
\hline Mean of pooled data & a $8050.9(813.1)$ & $258.8(86.7)$ & $2039.9(185.2)$ & $500.9(74.7)$ & $95.1(34.3)$ & $1277.3(190.8)$ & $25.7(9.8)$ \\
\hline
\end{tabular}

(T-GRSP, EE-GRSP) ranged from 0.1424 to 0.3489 , which was larger than those relations with soil bulk density $\left(R^{2}=\right.$ 0.1731 to 0.0748$)$ and soil moisture $\left(R^{2}=0.0825\right.$ to 0.0775$)$, showing that $\mathrm{pH}$ was the main abiotic factor regulating GRSP concentration changes (Figure 3).

Soil $\mathrm{pH}$ was the most important factor affecting compositional traits of T-GRSP, (Figure 4). Soil pH was significantly correlated with infrared functional trait II (aliphatic $\mathrm{C}-\mathrm{H}$ stretching, positive correlation), trait $\mathrm{V}$ (C-O stretching and
$\mathrm{O}-\mathrm{H}$ bending, positive correlation), trait VI (stretching of $\mathrm{C}-\mathrm{O}$ and $\mathrm{Si}-\mathrm{O}-\mathrm{Si}$, negative correlation), and relative crystallinity (negative correlation) $(P<0.05)$. However, no correlations were found between soil moisture, soil bulk density, and all compositional traits.

Significant correlations between composition-related parameters and T-GRSP concentration in soil were also found (Figure 5). Infrared related functional traits including I (stretching of $\mathrm{O}-\mathrm{H}, \mathrm{N}-\mathrm{H}, \mathrm{C}-\mathrm{H}$ ), VI (stretching of $\mathrm{C}-\mathrm{O}$ and 


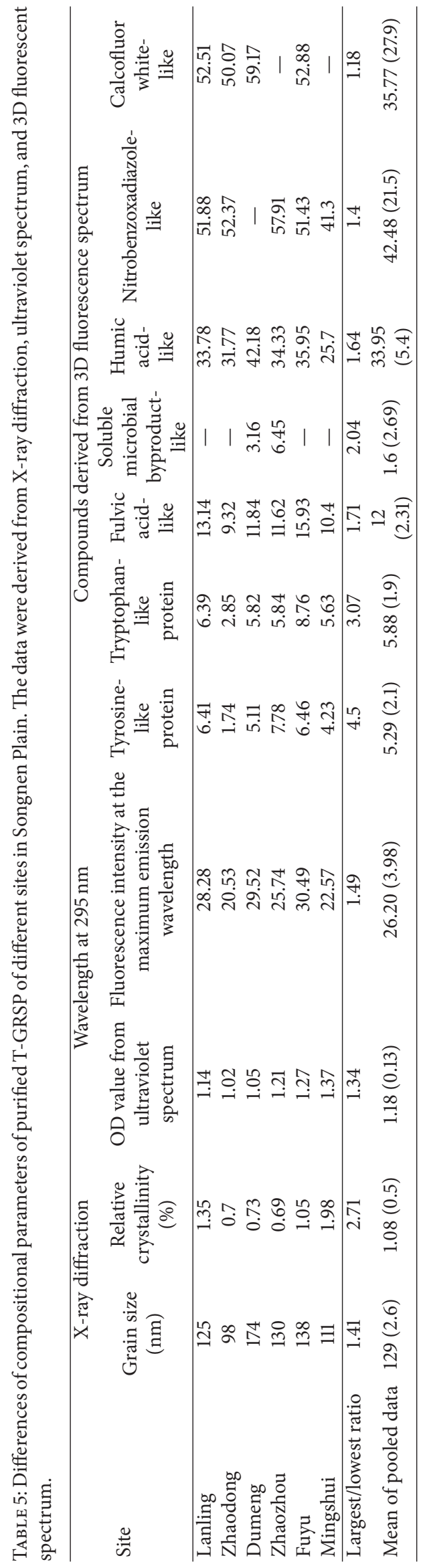



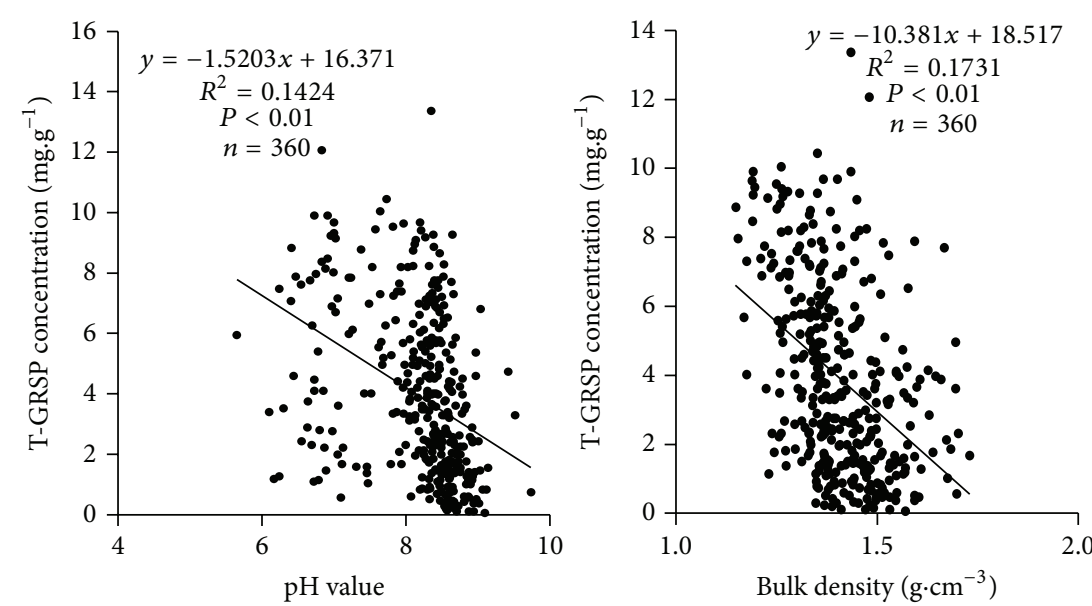

(a)

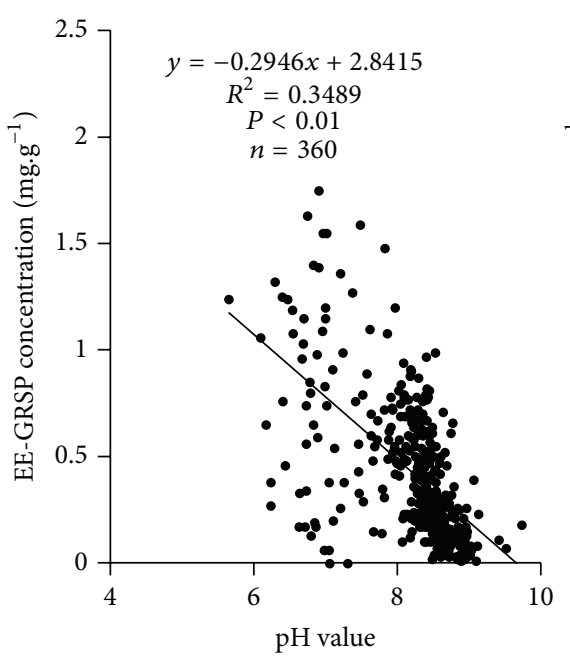

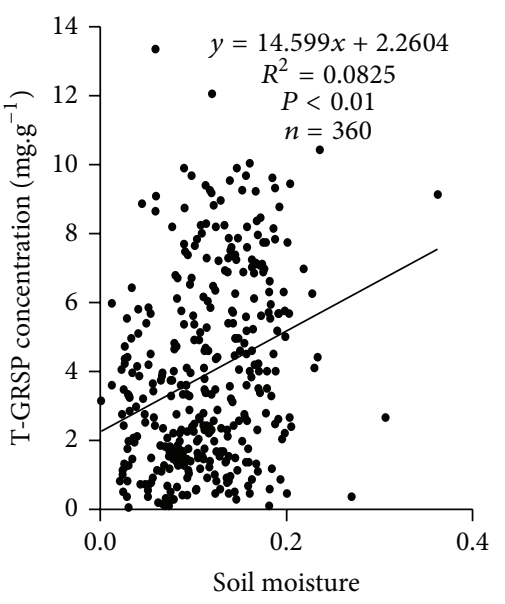

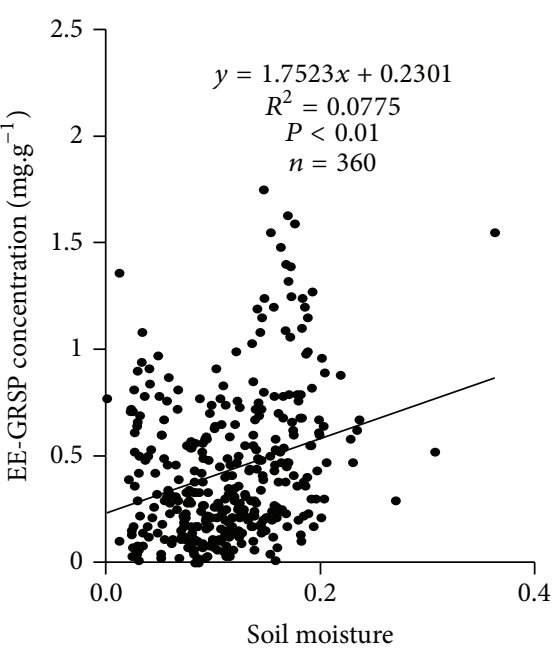

(b)

FIGURE 3: Correlations between soil pH, bulk density, moisture, and T-GRSP concentration (a) and between these parameters and EE-GRSP concentration (b).

$\mathrm{Si}-\mathrm{O}-\mathrm{Si}$ ), and $\mathrm{X}$-ray-related functional traits (relative crystallinity) showed significant positive correlations with TGRSP concentration $(P<0.05)$. 3D fluorescent compounds (humic acid-like) showed the significant negative correlations with GRSP (T-GRSP, EE-GRSP) $(P<0.05)$. T-GRSP storage usually showed a similar pattern (data not shown here).

\section{Discussion}

Since its discovery, GRSP has received wide investigation due to its significant role in the improvement of soil properties [26-28]. Many studies have reported that a variety of environmental factors, such as climate conditions, vegetation types, soil characteristics, atmospheric $\mathrm{CO}_{2}$, and land uses, could affect the accumulation of T-GRSP and EE-GRSP in soils [3, 29]. Compared with concentration changes, few studies have focused on composition changes, although their importance gets more and more concerns $[9,12]$. The working hypothesis of this paper was testified by the large GRSP spatial variations in both concentration and composition at different sites and vertical profiles are mainly related to soil $\mathrm{pH}$ changes, while the concentration of GRSP (instead of its compositional features) was mainly related to soil physics (soil bulk density).

4.1. Large Variations in GRSP Concentration in Poplar Shelterbelts: Comparison with References. The marked spatial variations in GRSP concentration were found in different sites and vertical soil profiles, and, as a finding of this paper, we quantified the range of the variations in Songnen Plain in shelterbelt plantations with the same poplar species. In the case of TGRSP, site variations were 3.04-3.14-fold, and vertical variations were 2.85-2.98 folds. In the case of EE-GRSP, the corresponding variations were, respectively, 3.81-3.95-fold and 2.46-2.58-fold (Table 3). Like our study, large spatial variations were also found in previous studies. For example, Tang et al. found that GRSP decreased with increasing soil depth in farmland (1.60-2.94 $\left.\mathrm{mg} \cdot \mathrm{g}^{-1}\right)$, artificial grassland (1.82$\left.3.18 \mathrm{mg} \cdot \mathrm{g}^{-1}\right)$, and orchard (1.41-1.91 $\left.\mathrm{mg} \cdot \mathrm{g}^{-1}\right)$ [7]. Decreasing 


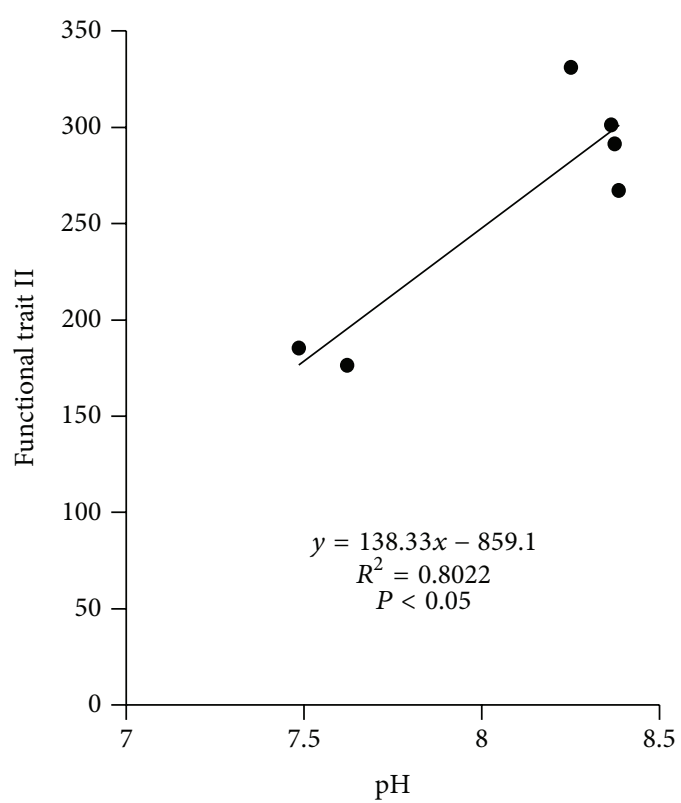

(a)

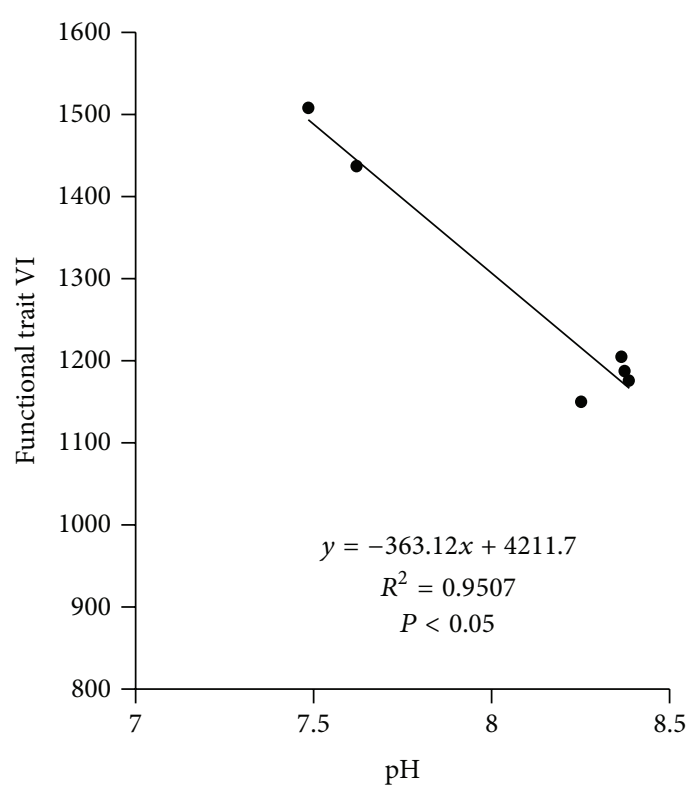

(c)

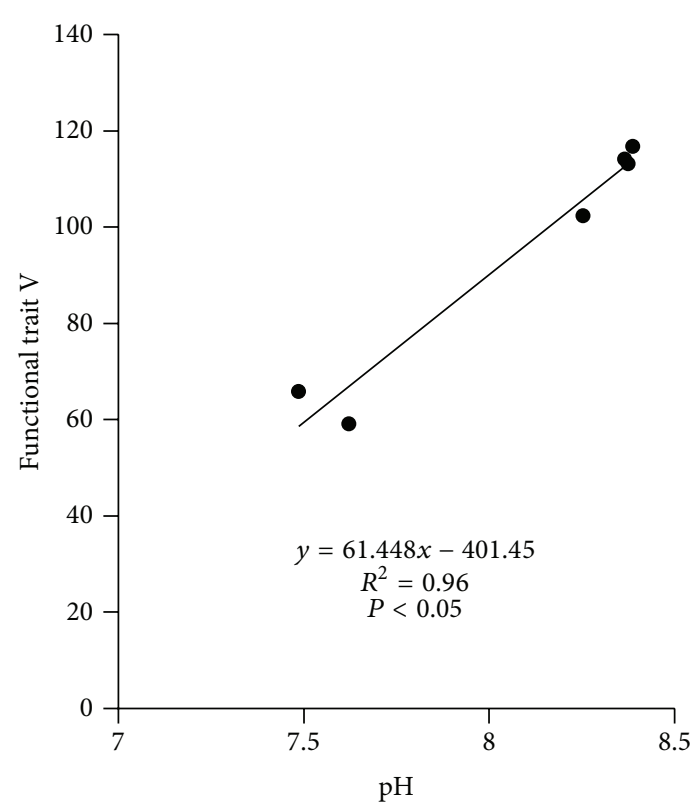

(b)

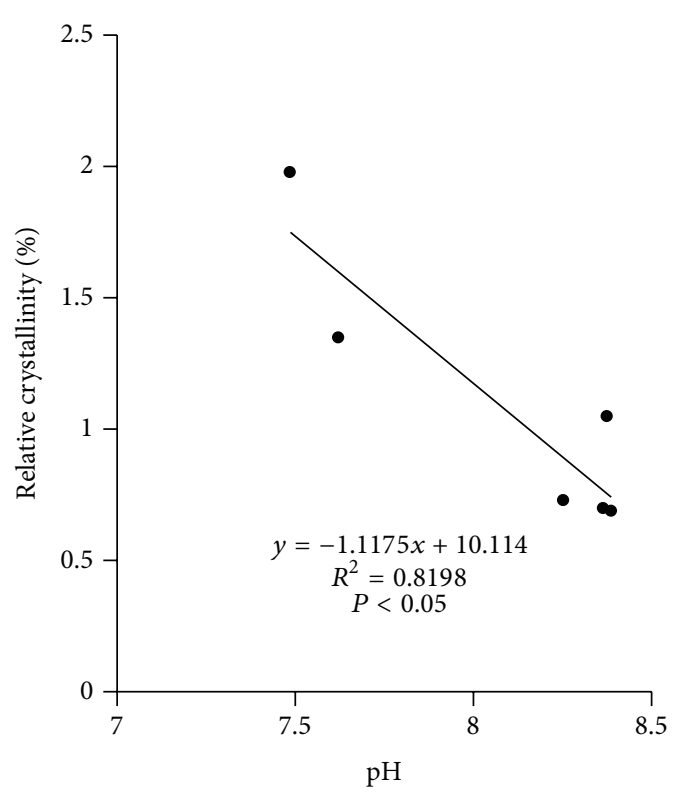

(d)

FIGURE 4: Correlations between soil $\mathrm{pH}$ and the concentration of functional trait II, V, VI, and relative crystallinity. Note: functional traits of II, V, and VI are the same as those in Figure 1.

GRSP with the increase of soil depth $(0-40 \mathrm{~cm})$ was found in the rhizosphere of a Citrus unshiu orchard, and the ranges of EE-GRSP and T-GRSP were, respectively, $0.3-0.6 \mathrm{mg} \cdot \mathrm{g}^{-1}$ and $0.5-0.8 \mathrm{mg} \cdot \mathrm{g}^{-1}$ [30]. Over 3 -fold site variations together with land uses influences were also reported, and the order was secondary forest $\left(3.47 \mathrm{mg} \cdot \mathrm{g}^{-1}\right)>$ paddy field $\left(2.87 \mathrm{mg} \cdot \mathrm{g}^{-1}\right)>$ rubber plantation $\left(2.27 \mathrm{mg} \cdot \mathrm{g}^{-1}\right)>$ orchard $\left(1.73 \mathrm{mg} \cdot \mathrm{g}^{-1}>\right.$ sugarcane $\left(1.03 \mathrm{mg}^{-1} \mathrm{~g}^{-1}\right.$ ) [31]. Even larger (16-fold) site variations in T-GRSP concentration were also found in different sites, with a good match with AMF activity [32]. About 1.5-fold spatial variations in GRSP concentration were also found between abandoned and active cultivation of olive groves [33]. GRSP concentration also differed in different soil sizefractions due to soil management [34]. All these studies manifested that land use changes, different sites, and vertical soil profiles induced large variations in GRSP concentration.

4.2. Compositional Clarifications of Purified GRSP and Its Spatial Variation: Replenishing Previous Studies. The composition of GRSP gets more and more attention in recent studies owing to its importance in exploring the function of GRSP in soil systems $[9,12]$. Infrared spectroscopy, X-ray diffraction, 


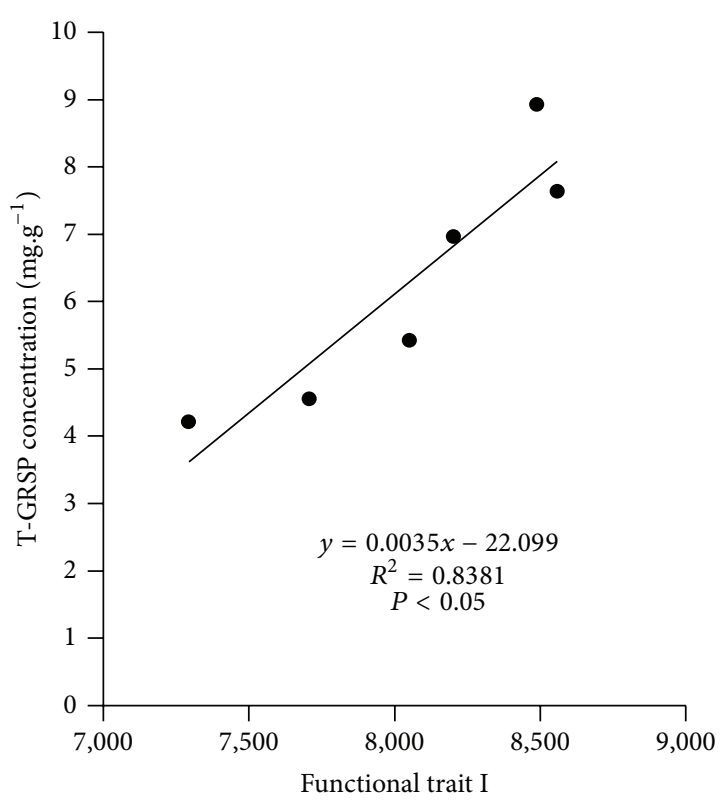

(a)

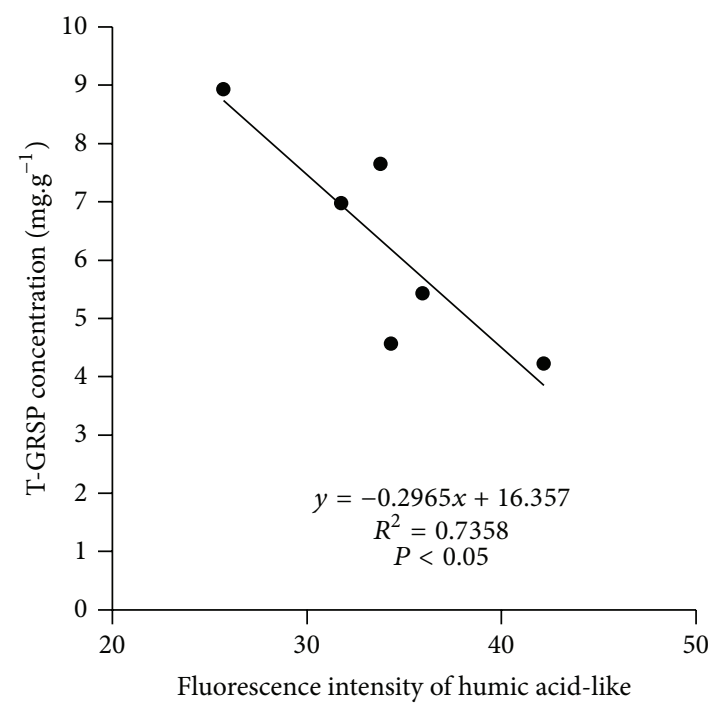

(c)

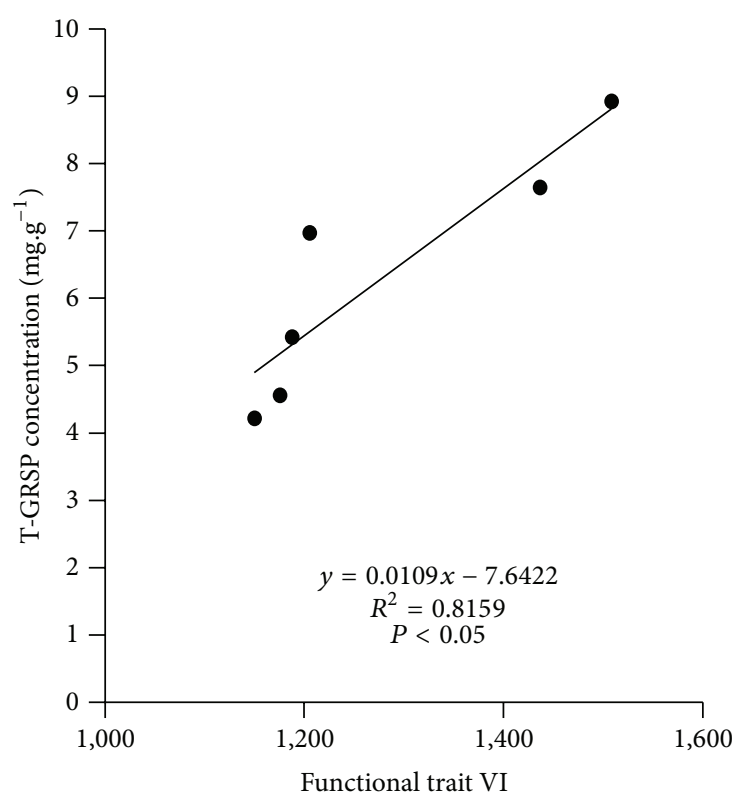

(b)

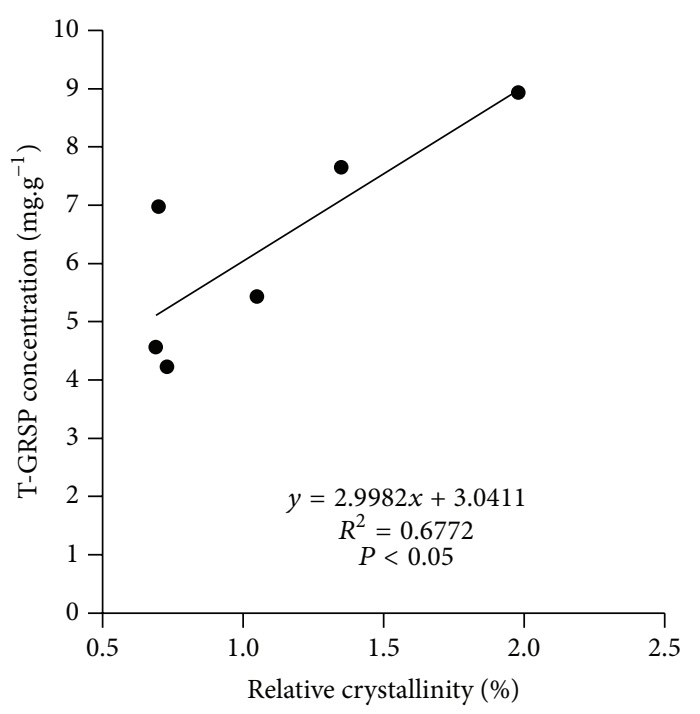

(d)

FIGURE 5: Correlations between T-GRSP concentration and the relative content of functional trait I, VI, fluorescence intensity of humic acid-like, and relative crystallinity. Note: functional traits of I and VI are the same as those in Figure 1.

and 3D fluorescence spectroscopy were used to characterize GRSP compositional traits in this paper, which is a complement of previous studies.

Infrared spectral scanning is suitable for the study of biological polymer structure and the polypeptide chain of configuration $[23,35,36]$. By using this technique, Schindler et al. found significant carboxylic functionality of GRSP [9], and we elucidated several functional traits in T-GRSP, that is, I: stretching of $\mathrm{O}-\mathrm{H}, \mathrm{N}-\mathrm{H}, \mathrm{C}-\mathrm{H}$ (8050.9); II: C-H stretching (258.8); III: stretching of $\mathrm{C}=\mathrm{O}$, $\mathrm{COO}-$ (2039.9); IV: COOstretching, $\mathrm{C}-\mathrm{H}$ bending (500.9); $\mathrm{V}$ : C-O stretching and $\mathrm{O}-\mathrm{H}$ bending (95.1); VI: stretching of C-O, Si-O-Si (1277.3); VII: $\mathrm{O}-\mathrm{H}$ bending (25.7) (Figure 1, Table 4). This has laid the foundation for the future studies of GRSP, which is one of the new discoveries and complements in GRSP functional traits.

$\mathrm{X}$-ray diffraction is suitable for the study of proteins of crystallization [12,37]. Gillespie et al. used this technology to characterize the gross chemical structure of GRSP at the atomic and molecular scale [12]. This information is useful toward determining the kinds of materials released by the extraction protocol of GRSP $[38,39]$, thus providing assessments of the bulk composition of GRSP. Gillespie et al. also revealed that glomalin is a rich mixture of proteinaceous, humic, lipid, and inorganic substances [12]. By using this technique, diffraction peak position $\left(2 \theta=19.8^{\circ}\right)$, average grain size $(129.3 \mathrm{~nm})$, and relative crystallinity $(1.08 \%)$ of 
purified T-GRSP were firstly defined (Table 5) and these data will provide a basis for future studies of GRSP.

$3 \mathrm{D}$ fluorescence spectroscopy was an effective method to study protein conformation in solution [40] and also detected dissolved organic matter fluorescence peaks [41]. Fluorescence detection in arbuscular mycorrhizal fungal structures and GRSP provided evidence of possible accumulation of $\mathrm{Al}$ in AM fungal structures and GRSP [42]. Fluorescent antibody was also used to detect hyphae and GRSP from AMF [43]. The $3 \mathrm{D}$ fluorescence spectra of GRSP in this paper proved that GRSP is a mixture of seven kinds of fluorescent substances: tyrosine-like protein, tryptophan-like protein, fulvic acid-like, soluble microbial byproduct-like, humic acid-like, nitrobenzoxadiazole-like, calcofluor white-like (Figure 2, Table 5). This finding replenished the discoveries of GRSP as a mixture of variable proteins and other substances [9].

Besides the concentration variations, compositional variations would be highly useful in identifying any ecological functions of GRSP in soils $[9,12]$, and we also quantified the site variations of these compositional traits in this paper (Tables 4 and 5). This study clearly manifested that significant spatial variations of GRSP were not only in its concentration, but also its compositional traits.

4.3. GRSP Concentration and Compositional Variations Were Regulated by Soil pH, While GRSP Concentration Was Related to Soil Bulk Density: Reason and Function from Regression Analysis. Although some studies tried to relate the concentration differences of T-GRSP and EE-GRSP to abiotic and biotic factors [8, 44], few papers have been devoted to the relations between GRSP compositional variations and soil properties. One of our important findings is that soil $\mathrm{pH}$ is mainly responsible for the observed differences both in GRSP concentration and compositional traits, while the regulations on soil physical properties (soil bulk density) are mainly from the GRSP amount (Table 2, Figures 3 and 4).

Previous study reported that the neutral or slightly acidic soil was suitable to the growth of plant roots and fungi [45]. Recent studies reported that soil $\mathrm{pH}$ negatively correlated with GRSP concentration [46-48]; our result also agreed with them. Moreover, correlations between soil $\mathrm{pH}$ and different infrared functional traits (aliphatic $\mathrm{C}-\mathrm{H}$ stretching, positive correlation; $\mathrm{C}-\mathrm{O}$ stretching and $\mathrm{O}-\mathrm{H}$ bending, positive correlation; stretching of $\mathrm{C}-\mathrm{O}, \mathrm{Si}-\mathrm{O}-\mathrm{Si}$, negative correlation) and relative crystallinity (negative correlation) were also generally observed. Soil $\mathrm{pH}$ directly affects the AM fungal formation [7], effectiveness of AMF for improving plant viability $[49,50]$, and synthesis and secretion of GRSP from AMF [51]. The finding of this paper manifested that the direct influences from $\mathrm{pH}$ on GRSP composition are on different functional groups from infrared spectrum as well as its X-ray features, such as crystallization. All these findings proved that soil acidity should be mainly responsible for variations in concentration and compositions of GRSP.

The role of GRSP in soil aggregate stability modification is well known [5]. Like previous study [49], the significant negative correlations between soil bulk density and GRSP concentration (T-GRSP, EE-GRSP) indicate their role in regulating soil structure. The relations between compositional traits (from infrared spectrum, X-ray diffraction, and 3D fluorescent spectrum) and soil bulk density were also tested in this paper, and none of them were statistical significant (figure not shown here). Thus, the concentration of GRSP, but not its compositional variations, mainly determines its function in soil structure modifications.

\section{Conclusions}

By using infrared spectrum, X-ray diffraction, and 3D fluorescent spectrum, we found the main infrared functional groups of GRSP, characteristic diffraction peak, relative crystallinity, grain size, and seven fluorescent substances. Like the large spatial variations in GRSP concentration, variations in compositional traits were quite large too. Soil $\mathrm{pH}$ changes were mainly responsible for these spatial variations. As a typical secretion from AMF, the GRSP-related findings are good for understanding the underlying mechanism of GRSP in soil functional maintenance.

\section{Conflict of Interests}

All the authors of this paper do not have any direct financial relation with the commercial identities mentioned in the paper that might lead to a conflict of interests.

\section{Acknowledgments}

This study was supported financially by the special research fund for public welfare of China forestry industry (201104002), Basic Research Fund for National Universities from Ministry of Education of China (2572014EA01), and China's National Foundation of Natural Sciences (31170575 and 41373075).

\section{References}

[1] S. F. Wright and A. Upadhyaya, "Extraction of an abundant and unusual protein from soil and comparison with hyphal protein of arbuscular mycorrhizal fungi," Soil Science, vol. 161, no. 9, pp. 575-586, 1996.

[2] S. F. Wright, M. Franke-Snyder, J. B. Morton, and A. Upadhyaya, "Time-course study and partial characterization of a protein on hyphae of arbuscular mycorrhizal fungi during active colonization of roots," Plant and Soil, vol. 181, no. 2, pp. 193-203, 1996.

[3] M. C. Rillig, S. F. Wright, K. A. Nichols, W. F. Schmidt, and M. S. Torn, "Large contribution of arbuscular mycorrhizal fungi to soil carbon pools in tropical forest soils," Plant and Soil, vol. 233, no. 2, pp. 167-177, 2001.

[4] C. E. Lovelock, S. F. Wright, and K. A. Nichols, "Using glomalin as an indicator for arbuscular mycorrhizal hyphal growth: an example from a tropical rain forest soil," Soil Biology and Biochemistry, vol. 36, no. 6, pp. 1009-1012, 2004.

[5] S. F. Wright and A. Upadhyaya, "A survey of soils for aggregate stability and glomalin, a glycoprotein produced by hyphae of arbuscular mycorrhizal fungi," Plant and Soil, vol. 198, no. 1, pp. 97-107, 1998.

[6] C. Chemini and A. Rizolli, "Land use change and biodiversity conservation in the Alps," Journal of Mountain Ecology, supplement 7, pp. 1-7, 2003. 
[7] H. L. Tang, L. Liu, L. Wang et al., "Effect of land use type on profile distribution of glomalin," Chinese Journal of Ecological Agriculture, vol. 17, no. 6, pp. 1137-1142, 2009.

[8] C. Rausch, P. Daram, S. Brunner et al., "A phosphate transporter expressed in arbuscule-containing cells in potato," Nature, vol. 414, no. 6862, pp. 462-466, 2001.

[9] F. V. Schindler, E. J. Mercer, and J. A. Rice, "Chemical characteristics of glomalin-related soil protein (GRSP) extracted from soils of varying organic matter content," Soil Biology and Biochemistry, vol. 39, no. 1, pp. 320-329, 2007.

[10] H. C. Cao, "Determination of content in proteins by UV spectrophotometric," Guangdong Chemical Industry, vol. 35, no. 8, pp. 93-95, 2007.

[11] Y. X. Yin, B. Q. Xiang, and L. Tong, "The application of studying fluorescence spectroscopy on protein," Experimental Technology and Management, vol. 27, no. 2, pp. 33-36, 2010.

[12] A. W. Gillespie, R. E. Farrell, F. L. Walley et al., "Glomalinrelated soil protein contains non-mycorrhizal-related heatstable proteins, lipids and humic materials," Soil Biology and Biochemistry, vol. 43, no. 4, pp. 766-777, 2011.

[13] J. F. Du, B. Zhang, H. T. Xie et al., "The effect of fertilization treatments on the concentration of GRSP," Chinese Journal of Soil Science, vol. 42, no. 3, pp. 573-577, 2011.

[14] M. C. Rillig, F. T. Maestre, and L. J. Lamit, "Microsite differences in fungal hyphal length, glomalin, and soil aggregate stability in semiarid Mediterranean steppes," Soil Biology and Biochemistry, vol. 35, no. 9, pp. 1257-1260, 2003.

[15] S. G. Fang, "Silviculture of poplar plantation in China: a review," Chinese Journal of Applied Ecology, vol. 19, no. 10, pp. 2308-2316, 2008.

[16] X. L. Li and G. Feng, Ecology and Physiology of VA Mycorrhizaes, Huawen Press, Beijing, China, 2001.

[17] Y. C. Song, X. L. Li, G. Feng, and F. S. Zhang, "A simple demonstration of acid phosphatase activity in the mycorrhizal sphere and hyphalsphere," Chinese Science Bulletin, vol. 50, no. 1, pp. 187-191, 2000.

[18] J. D. Graves, N. K. Watkins, A. H. Fitter, D. Robinson, and C. Scrimgeour, "Intraspecific transfer of carbon between plants linked by a common mycorrhizal network," Plant and Soil, vol. 192, no. 2, pp. 153-159, 1997.

[19] M. C. Rillig, "Arbuscular mycorrhizae and terrestrial ecosystem processes," Ecology Letters, vol. 7, no. 8, pp. 740-754, 2004.

[20] Z. T. Gong, G. L. Zhang, Z. C. Chen et al., Pedogenesis and Soil Taxonomy, Science Press, Beijing, China, 2007.

[21] S. F. Wright, V. S. Green, and M. A. Cavigelli, "Glomalin in aggregate size classes from three different farming systems," Soil and Tillage Research, vol. 94, no. 2, pp. 546-549, 2007.

[22] H. J. Lü, D. H. Liu, Y. H. Dong, and J. Li, "Determination of factors affecting glomalin-related soil protein with bradford method," Journal of Ecology and Rural Environment, vol. 27, no. 5, pp. 93-97, 2011.

[23] C. T. Johnston and Y. O. Aochi, "Fourier transform infrared and Raman spectroscopy," Soil Science Society of America, part 3, pp. 269-321, 1996.

[24] B. Xu, J. M. Man, and C. X. Wei, "Methods for determining relative crystallinity of plant starch X-ray powder diffraction spectra," Chinese Bulletin of Botany, vol. 47, no. 3, pp. 278-285, 2012.

[25] W. Chen, P. L. Westerhoff, J. A. Leenheer, and K. Booksh, "Fluorescence excitation-emission matrix regional integration to quantify spectra for dissolved organic matter," Environmental Science and Technology, vol. 37, no. 24, pp. 5701-5710, 2003.
[26] M. C. Rillig, F. T. Maestre, and L. J. Lamit, "Microsite differences in fungal hyphal length, glomalin, and soil aggregate stability in semiarid Mediterranean steppes," Soil Biology and Biochemistry, vol. 35, no. 9, pp. 1257-1260, 2003.

[27] R. M. Miller and J. D. Jastrow, Mycorrhizal Fungi Influence Soil Structure, Kluwer Academic Press, New York, NY, USA, 2000.

[28] M. C. Rillig, "Arbuscular mycorrhizae, glomalin, and soil aggregation," Canadian Journal of Soil Science, vol. 84, no. 4, pp. 355363, 2004.

[29] S. Bedini, L. Avio, E. Argese, and M. Giovannetti, "Effects of long-term land use on arbuscular mycorrhizal fungi and glomalin-related soil protein," Agriculture, Ecosystems and Environment, vol. 120, no. 2-4, pp. 463-466, 2007.

[30] Q. S. Wu, X. H. He, Y. N. Zou, K. He, Y. Sun, and M. Cao, "Spatial distribution of glomalin-related soil protein and its relationships with root mycorrhization, soil aggregates, carbohydrates, activity of protease and $\beta$-glucosidase in the rhizosphere of Citrus unshiu," Soil Biology and Biochemistry, vol. 45, pp. 181183, 2012.

[31] F. Zhu, Q. H. Zhao, W. G. Deng et al., "Relationships among glomalin related soil protein, Soc and soil texture under different land use types," Agricultural Sciences, vol. 38, no. 23, pp. 1249912502, 2010.

[32] X. L. He, C. Chen, and B. He, "Spatial distribution of arbuscular mycorrhizal fungi and glomalin of Hippophae rhamnoides $\mathrm{L}$ in farming-pastoral zone from the two northern provinces of China," Acta Ecologica Sinica, vol. 31, no. 6, pp. 1653-1661, 2011.

[33] C. Hontoria, R. Velásquez, M. Benito, J. Almorox, and A. Moliner, "Bradford-reactive soil proteins and aggregate stability under abandoned versus tilled olive groves in a semi-arid calcisol," Soil Biology and Biochemistry, vol. 41, no. 7, pp. 1583$1585,2009$.

[34] S. F. Wright, V. S. Green, and M. A. Cavigelli, "Glomalin in aggregate size classes from three different farming systems," Soil and Tillage Research, vol. 94, no. 2, pp. 546-549, 2007.

[35] J. T. Chen, Y. P. Zhao, Z. Xu et al., "FT-IR Spectrometric study of reconbinant collagen and borine tendon type I colleagen," Materials Review, vol. 22, no. 3, pp. 119-121, 2008.

[36] Y. H. Li, H. M. Wang, W. J. Wang et al., "Ectomycorrhizal influence on particle size, surface structure, mineral crystallinity, functional group, and elemental composition of soil colloids from different soil origins," The Scientific World Journal, vol. 2013, Article ID 698752, 13 pages, 2013.

[37] A. P. Hitchcock, C. Morin, X. Zhang et al., "Soft X-ray spectromicroscopy of biological and synthetic polymer systems," Journal of Electron Spectroscopy and Related Phenomena, vol. 144-147, pp. 259-269, 2005.

[38] J. Stewart-Ornstein, A. P. Hitchcock, D. H. Cruz et al., "Using intrinsic X-ray absorption spectral differences to identify and map peptides and proteins," Journal of Physical Chemistry B, vol. 111, no. 26, pp. 7691-7699, 2007.

[39] Y. Zubavichus, A. Shaporenko, M. Grunze, and M. Zharnikov, "Is X-ray absorption spectroscopy sensitive to the amino acid composition of functional proteins?" Journal of Physical Chemistry B, vol. 112, no. 15, pp. 4478-4480, 2008.

[40] Y. Yan, J. G. Xu, and G. Z. Chen, "Studies on the conformation of protein solution by three- dimensional fluorescence spectrum," Science in China B, vol. 27, no. 1, pp. 16-22, 1997.

[41] J. A. Leenheer and J. Croué, "Characterizing aquatic dissolved organic matter," Environmental Science and Technology, vol. 37, no. 1, pp. 19A-26A, 2003. 
[42] P. Aguilera, F. Borie, A. Seguel, and P. Cornejo, "Fluorescence detection of aluminum in arbuscular mycorrhizal fungal structures and glomalin using confocal laser scanning microscopy," Soil Biology and Biochemistry, vol. 43, no. 12, pp. 2427-2431, 2011.

[43] S. F. Wright, "A fluorescent antibody assay for hyphae and glomalin from arbuscular mycorrhizal fungi," Plant and Soil, vol. 226, no. 2, pp. 171-177, 2000.

[44] S. Bedini, E. Pellegrino, L. Avio et al., "Changes in soil aggregation and glomalin-related soil protein content as affected by the arbuscular mycorrhizal fungal species Glomus mosseae and Glomus intraradices," Soil Biology and Biochemistry, vol. 41, no. 7, pp. 1491-1496, 2009.

[45] R. J. Liu and X. L. Li, Arbuscular Mycorrhizae and Its Application, Science Press, Beijing, 2000.

[46] C. Y. Wang, H. Y. Feng, Z. F. Yang et al., "Glomalin-related soil protein distribution and its environmental affecting factors in the Northeast Inner Mongolia," Arid Zone Research, vol. 30, no. 1, pp. 22-28, 2013.

[47] X. L. He, C. M. Bai, and L. L. Zhao, "Spatial distribution of arbuscular mycorrhizal fungi in Astragalus adsurgens rootzone soil in $\mathrm{Mu}$ Us sand land," Chinese Journal of Applied Ecology, vol. 19, no. 12, pp. 2711-2716, 2008.

[48] Z. Chen, X. L. He, H. J. Guo et al., "Diversity of Arbuscular mycorrhizal fungi in the rhizosphere of three host plants in the farming-pastoral zone, north China," Symbiosis, vol. 57, pp. 149$160,2012$.

[49] F. S. Wu, M. X. Dong, Y. J. Liu et al., "Effects of long-term fertilization on AM fungal community structure and Glomalinrelated soil protein in the Loess Plateau of China," Plant and Soil, vol. 342, no. 1-2, pp. 233-247, 2011.

[50] M. C. Rillig and M. F. Allen, "What is the role of arbuscular mycorrhizal fungi in plant-to-ecosystem responses to elevated atmospheric $\mathrm{CO}_{2}$ ?" Mycorrhiza, vol. 9, no. 1, pp. 1-8, 1999.

[51] J. Yan and W. Peiyi, "Study of soy protein by mid-infrared spectroscopy and near-infrared spectroscopy," Progress in Chemistry, vol. 21, no. 4, pp. 705-714, 2009. 

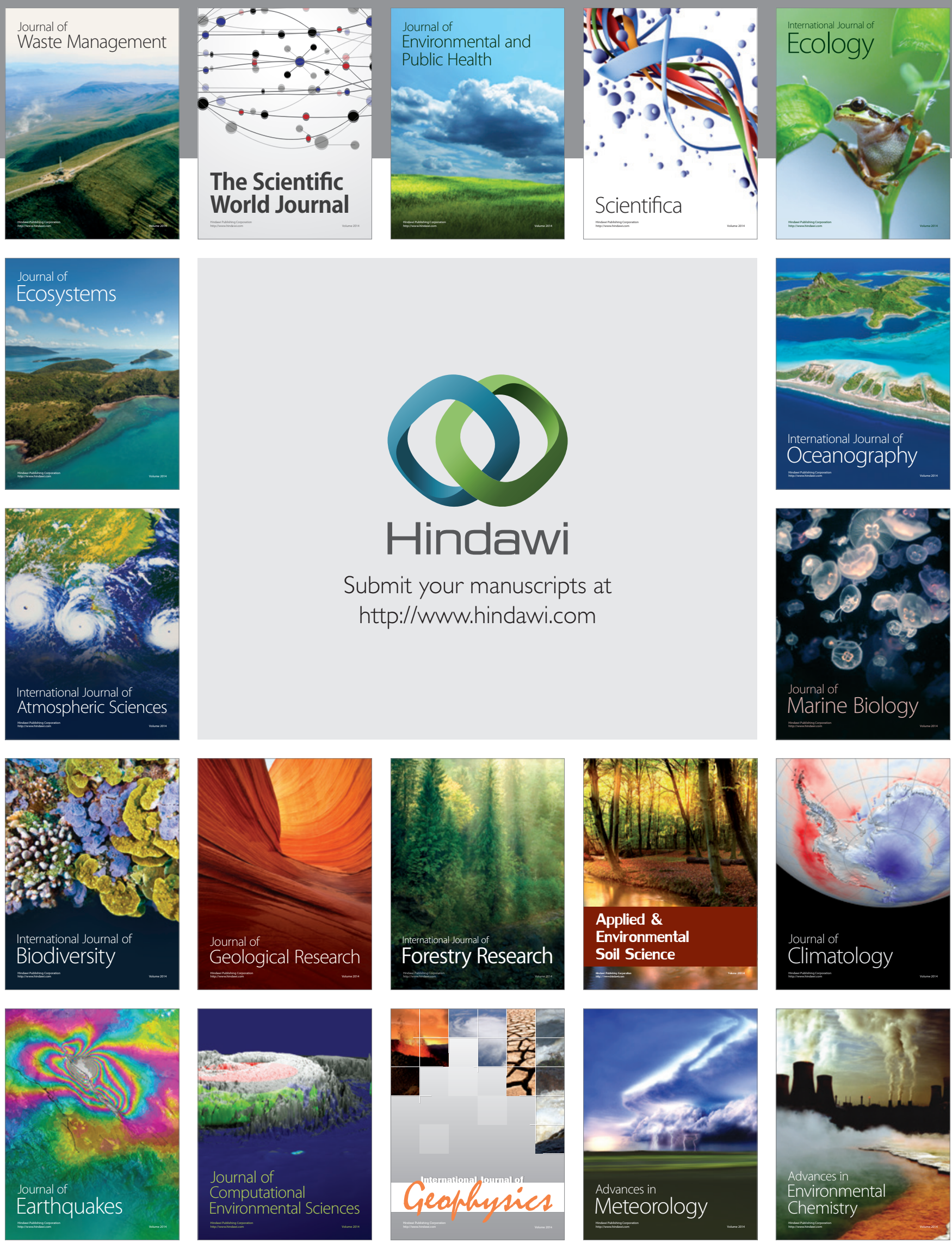